\title{
CFEBT RISK TRIANGLE AS A TOOL FOR DETECTING AND EVALUATING RISKS OF ACCOUNTING RECORDS: A CASE STUDY
}

\author{
Zita Drábková ${ }^{1}$ \\ ${ }^{1}$ Department of Finance and Accounting, Faculty of Economics, University of South Bohemia in České Budějovice, \\ Studentská 13, 37005 České Budějovice, Czech Republic
}

\begin{abstract}
DRÁBKOVÁ ZITA. 2018. CFEBT Risk Triangle as a Tool for Detecting and Evaluating Risks of Accounting Records: a Case Study. Acta Universitatis Agriculturae et Silviculturae Mendelianae Brunensis, 66(3): 747-754.

The objective of the present contribution is to evaluate the risk of accounting errors and frauds in small companies predominantly operating in agriculture. It is based on an analysis of the CFEBT risk triangle for financial statements reported for the years 2012-2016.

The CFEBT risk triangle is applied in form of a case study aimed at risk detection of occurrence of accounting errors and frauds for a selected sample of companies. A detailed analysis of a risk of impact of accounting errors and frauds is illustrated in the case study of an accounting unit chosen from the sample of companies evaluated. Results of the presented case study into the detection and evaluation of the risk based on interconnections between the reported profit (loss) and the generated cash flow during 5 accounting periods confirm the significance of having a complex view for decisionmaking of users based on reported accounting records and accounting data.

Future research into the CFEBT risk triangle focuses on performance of complex analyses for individual types of business activities of small and middle-sized companies in the context of Czech accounting standards and IFRS.
\end{abstract}

Keywords: creative accounting, CFEBT risk triangle of accounting errors and frauds, financial statements, risk of financial statements, fair and true view, frauds, accounting errors

\section{INTRODUCTION}

It is essential that accounting records present a true and fair view of real facts. For most interest groups, accounting information continues to serve as the basic information source about companies. It is therefore a matter of logic that individual interest groups look for different values. The objective of the present contribution is to evaluate the risk of accounting errors and frauds in small companies predominantly operating in agriculture based on analysis of the CFEBT risk triangle for financial statements reported for the years 2011-2017.

The CFEBT risk triangle is applied in form of a case study aimed at risk detection of occurrence of accounting errors and frauds for a selected sample of companies. A detailed analysis of a risk of impact of accounting errors and frauds is illustrated in the case study of an accounting unit chosen from the sample of companies evaluated.

Accounting frauds cannot be entirely suppressed, and toughening of prison sentences may not always be the right answer, as attested by the American approach. The fight against creative accounting surpassing the bounds of the true and fair view of accounting has gained in importance especially as a consequence of scandals of a number of renowned European and American companies (Enron, WorldCom, Tyco, Lehman Brothers) and scandals that came to light in the Czech Republic. Results of studies performed by leading audit companies have presented the importance of these problems at the level of consequences and costs of solutions for business corporations in the Czech Republic, Europe and other countries. 
According to the Association of International Certified Professional Accountants, it is estimated that corruption costs the global economy approximately 1.5 trillion dollars a year. Whereas only a small percentage of loss from frauds is attributable to organizations, a higher percentage is achieved in this sense by senior officers and managerial staff. Organizations may accordingly lose as many as $7 \%$ of their total turnover per year as a consequence of a frauds (CIMA, 2009). In this connection, Henselmann, Hofmann (2010) list the worst ten financial scandals in the last years. In accordance with the White Book prepared by PwC, which works with data until 2014, companies exert utmost effort to solve frauds at the detriment of their business activities and as a result, they face an increase in costs. The document argues that $77 \%$ managers said that they lost precious time when having to solve consequences of frauds (PWC, 2014).

Companies are confronted with the task of implementing information technologies in forensic activities, improvement of internal information systems by introducing effective internal controls based on mutual links in the financial and managerial accounting. An increase in effectiveness of internal control systems should proceed from complex relations between accounting and management of companies such that companies reduce the information asymmetry between creators and users of accounting records by setting up suitable "anti-fraud" systems detected by them on the basis of a data analysis, by measuring the risk of accounting frauds adequately and therefore the ascertained risk may be responded to by introducing measures placed in the "right" direction. In addition, another reason may be rooted in the effort to conceal the real facts arising from accounting records, for example, a fact that the given company undergoes a financial crisis, is insolvent, or its bankruptcy is imminent.

The Oxford Dictionary defines fraud as "criminal deception; the use of false representations to gain an unjust advantage". Detection of frauds lies in the identification of frauds that is done as fastest as possible after any such fraud is committed. Frauds are uncovered following the failure of the prevention against frauds (Bolton and Hand 2002).

Brody, Melendy Perri, F.S. (2012) distinguish between forensic accounting and fraud examination. Forensic accounting is a broader term that includes the use of accounting for investigation of frauds that concern, for example, company acquisitions, divorce proceedings, settlement with insurance companies or other legal areas. Fraud examination may be described as an investigation related to prevention, detection, investigation and prosecution of criminal activities of accountants and managers.

One of the many problems in the detection of frauds is that for each fraudulent record, there exist a large number of entirely legitimate accounting records. The major problem is that to find one fraudulent record means to verify all other records, whereas significant costs are expended. (Bolton and Hand, 2002)

Models engaged in the detection of creative accounting are based on a detailed examination of corporate accounting records. By using individual tools and techniques, the objective of these models is to verify whether there exists a possibility of manipulation of the financial statements or other accounting records. The main groups of manipulation methods with accounting records in relation to identification include some groups of creative accounting methods as increase in income, reduction in liabilities, decrease in expenses, increase in assets and increase in operating cash flow (Jones, 2011).

The financial statements represent a significant source of information for users of financial statements, i.e. the owners, Corporate Governance, potential investors, the state, creditors, customers and the public. Regarding the information asymmetry acting among record creators and users, it is necessary to search for tools and possibilities enabling its decrease, or identification of risk of the reliability of the presented accounting records (Drábková, 2017). Results of the Romanian research showed that more than a half of managers included in the sample has a tendency to change accounting principles that contribute considerably to the corporate image, and that there is a certain aversion to risks in relation to managers (Balaciu, Bogdan, Feleaga and Popa, 2014).

The issue of prevention and detection of accounting frauds is also tackled in Steve Dawson's publication. Steve presents the six elements of an effective anti-fraud programme-fraud risk assessment, control activities, information, communication, anti-fraud environment and monitoring (Dawson, 2015). Every year, departments engaged in investigation of corporate frauds receive dozens of reports of accusations of potential frauds. The need to discover a method for detection of risks of frauds with the aim of a fast solution is mentioned by a wide array of publications and research papers, such as (Caplan, 1994; Bloomfield, 1995). Moreover, research results of a large telecommunication company imply that technical checks detect a mere one third of cases of frauds. More complex frauds are detected by a number of technical and social-technical checks both from the inside and outside of companies (Goode and Lacey, 2011).

The fraud triangle underwent criticism, which revealed the existence of three inadequately examined problems: rationalization of a perpetrator's fraudulent conduct; nature of collusion in frauds; regulatory attempts to support the distribution of reports. These themes highlight the perspective of persons who are directly 
involved in frauds, and link the queries formed during decades by involved scholars from other fields to the queries that are at the fore of the current financial management the world over (Free, 2015). Similarly, Schuchter and Lévi (2015) argue that the term "rationalization" is too simplified within the proposed fraud triangle. This research is used to illustrate certain measures the adoption of which by companies may contribute to a low rate of risks of frauds in the corporate culture. These two authors maintain that-when it comes to frauds-even though an opportunity is a necessary but not adequate condition for committing a crime, their respondents believe that the pressure they have been subjected to is the main cause for committing a fraud (Schuchter and Levi, 2016). Mui and Mailley (2015) apply the fraud triangle by using scenarios of misuse of assets according to different types of perpetrators: external perpetrators, employees, management, Board of Directors and controlling bodies. The result of their study is a certain restriction of the fraud triangle, the focus of which is perpetrators of frauds. The authors argue that to gain a complex view of the fraudulent event, the triangle should be supplemented with a perspective of the environment where the fraud is committed.

The CFEBT risk triangle was designed as a complex tool for detection and management of accounting errors and frauds on the basis of results of long-term research in relations and interconnections among accounting records in the circumstances of the Czech accounting standards and IFRS (Drábková, 2017). One of the advantages of the CFEBT approach of the risk triangle is the interconnection of the perspective of a financial analysis with the economic substance of interconnections between reported accounting information, which enables its utilization in conditions of various accounting systems. One disadvantage that this approach may have could be perceived in the high demands for available data of comparable accounting units.

\section{MATERIALS AND METHODS}

The calculation of the CFEBT score proceeds from the hypothesis that there is a tendency to head for similar results upon observance of changes of cash flow without influence of taxes and generated earnings (CFEBT) before tax for at least 5 accounting periods. The M-score was designed at the first level as an analytical test which is followed by a detailed analysis of non-monetary expenses and revenues in a modified calculation of the second level of the M-score. In pursuance of a complex overview of all interconnections, a calculation of the third level of the M-score is included: this calculation observes the influence of interconnections of generated outputs of cash flow and CFEBT in the operating area.
To present a detailed analysis in the case study, one accounting unit was selected that was ascertained to have the first level of $\mathrm{M}$-score above the determined level of materiality, and a detailed analysis was performed as to causes and impacts of risks of manipulation of accounting records in terms of accounting errors and frauds beyond the framework of true and fair view of accounting.

The analysis makes use of the CFEBT model, which was designed for the individual levels of detailed analysis of interconnections among financial statements:

The first level of M-score of the CFEBT model is defined as follows:

$C F E B T=\frac{\sum_{\mathrm{t}=1}^{\mathrm{n}} \mathrm{CFt}-\sum_{\mathrm{t}=1}^{\mathrm{n}} \mathrm{EBTt}}{\sum_{\mathrm{t}=1}^{\mathrm{n}} \mathrm{EBTt}} \times 100$

CF - Total increase or decrease in cash flow before tax during the observed period $t$

EBT - Earnings before tax, generated during the observed period

If CFEBT $\geq$ materiality, a detailed test of links of impacts has to follow in the second and third levels of M-score. (Drábková, 2013; 2015)

The second level of M-score of the CFEBT model (a modified CFEBT score) complies with the established hypothesis as to the connection between the generation of cash flow and earnings. This level modifies the monetary means and monetary equivalents for the observed accounting period by changes of balances of assets and liabilities which represent potential additions or loss of monetary means. The sum of EBT generated during the observed period is modified by the costs that are reported as non-monetary expenses:

$$
\text { CFEBTm }=\frac{\sum_{\mathrm{t}=1}^{\mathrm{n}} \mathrm{CF} m_{\mathrm{t}}-\sum_{\mathrm{t}=1}^{\mathrm{n}} \mathrm{EBT} m_{\mathrm{t}}}{\sum_{\mathrm{t}=1}^{\mathrm{n}} \mathrm{EBT} m_{\mathrm{t}}} \times 100
$$

Where:

CFm - Increase in cash flow before tax in the observed period, modified by reported future cash in- and out-flows

EBTm - Earnings before tax generated during the observed period, modified by non-monetary expenses

The third level of M-score of the CFEBT model expresses the ratio between operating cash flow generated during the observed period and modified earnings for the observed accounting period. A percentage result presents the ratio between the generated cash flow from operating activities and the generated earnings, which include only the expenses and revenues that are directly converted to cash flow during the current or future accounting periods. 


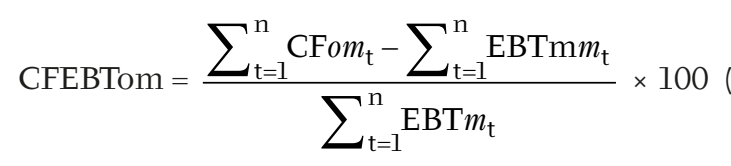

Where:

CFom: increase in operative cash flow before taxes in the analysed period

EBTm: earnings before taxes gained for the analysed period modified by non-monetary expenses

For a statistical analysis of causes of accounting errors and frauds, seven financial indicators were designed for the individual accounting periods, and these indicators allow a comparison between cash flow and earnings in terms of accounting, i.e. net of income taxes:

Return on Assets (ROA) $=\frac{\text { EAT }}{\text { TOTAL ASSETS }}$

Cash Flow Return on Assets (CFA) =

$$
=\frac{\mathrm{CF}_{\mathrm{AT}}}{\text { TOTAL ASSETS }}
$$

Where:

CFAT: cash flow of the given accounting period after taxes

Return on Equity $($ ROE $)=\frac{\text { EAT }}{\text { EQUITY CAPITAL }}$

Cash Flow Return on Equity $(\mathrm{CFE})=$

$$
=\frac{C F_{A T}}{\text { EQUITY CAPITAL }}
$$

Where:

CFAT: cash flow of the given accounting period after taxes

Expense Personnel Productivity $(\mathrm{EPP})=$

$$
=\frac{\text { OPERATIONS }}{\text { PERSONNEL EXPENSES }}
$$

Where:

OPERATIONS....... operating revenues (sales of goods and performances)

Financial Personnel Productivity $(\mathrm{FPP})=$
$=\frac{C F_{\mathrm{AT}}}{\text { PERSONNEL EXPENSES }}$

Total Accruals to Total Assets (TATA) $=$

$$
=\frac{\text { EAT }-C F_{\text {AT }}}{\text { TOTAL ASSETS }}
$$

The analysis addresses several monitored periods for selected accounting unit with respect to available data for 5 accounting periods from 2012 to 2016. The selected sample includes small accounting units, based on the average number of employees, which, for the selected accounting units, is more than 10 but does not exceed 50. The comparable accounting units are predominantly engaged in agriculture. The total of 1,318 accounting units was included in the analysis. The Albertina database Gold Edition was used for processing the reported data of financial statements of the companies.

The CFEBT risk triangle was designed as a complex tool for detection and management of accounting errors and frauds on the basis of results of longterm research in relations and interconnections among accounting records in the circumstances of the Czech accounting standards and IFRS.

\section{RESULTS}

For testing the risks of causes (motivation) of occurrence of accounting errors and frauds, the analysis operates with as many as 5,668 tested elements (data rows) for the analysed accounting periods of selected accounting units in order to calculate the 7 selected financial indicators, median value, frequency of occurrence in the set, and consequently, the calculation of a deviation from the median value, the standard deviation and the ratio of a deviation to the standard deviation

In addition, the total of 4,985 tested elements (including zero values) is included in the analysis of 14 selected items of financial statements for calculating the percentage of a share of an accounting item in the turnover, median values, frequency of occurrence in the set, and subsequently, for calculating a deviation from the median value of the set, the standard deviation, and the ratio of a deviation to the standard deviation. One accounting unit was selected

\begin{tabular}{|c|c|c|c|}
\hline $\begin{array}{l}\text { Analysis of risk of impact of accounting errors } \\
\text { and frauds - Ist to 3rd levels of CFEBT }\end{array}$ & $\begin{array}{l}1^{\text {st }} \text { level } \\
\text { M-score }\end{array}$ & $\begin{array}{l}2^{\text {nd }} \text { level } \\
\text { M-score }\end{array}$ & $\begin{array}{l}3^{\text {rd }} \text { level } \\
\text { M-score }\end{array}$ \\
\hline Taxable entity & Basic & Modified & M-Operative \\
\hline$\Delta \mathbf{C F}^{*}$ & 1480 & 28098 & -18144 \\
\hline$\Sigma$ EBT & -18705 & -18144 & -18144 \\
\hline
\end{tabular}
for a detailed analysis within the case study; for this accounting unit, the $1^{\text {st }}$ level of M-score

I: CFEBT for a selected accounting unit-- $1^{\text {st }}$ to $3^{\text {rd }}$ levels of $M$-score

*an increase in cash flow of reviewed accounting periods in thousand 
was determined highly above the determined threshold of materiality $10 \%$, and a detailed analysis was performed for causes and impact of risks of manipulation of accounting records from the perspective of accounting errors and frauds above the true and fair view of accounting.

\section{CFEBT risk triangle-risk of impact of accounting errors and frauds}

The detection of risk items for individual entities may be followed by a detailed analysis, which examines the impact of these items in a long-term context of relations between financial statements.

This vertex of the anti-fraud CFEBT approach, the M-score of the first, second and third levels is calculated. Comparison of individual percentage values of the score makes it possible to evaluate any impacts of CF and EBT over a longer period (at least five accounting periods).

The calculation of CFEBT enables a user of financial statements to amend his/her view of financial statements by interrelations of cash flow

II: Modification items of the $2^{\text {nd }}$ level of $M$-score of CFEBT model

\begin{tabular}{|c|c|c|c|}
\hline Item no.** & Description of item (modification, informative, operating)* & $\begin{array}{l}\text { Change of item n } \\
\text { in TCZK }\end{array}$ & n/EBT in \% \\
\hline 1 & Receivables -1, from members & 0 & 0 \\
\hline 2 & Receivables -2 , from controlled and managed entities & 0 & 0 \\
\hline 3 & Receivables -3 , from accounting units with substantial influence & 0 & 0 \\
\hline 4 & Receivables -4 , trade receivables & 0 & 0 \\
\hline 5 & Receivables -5 , from institutions & -21 & 0 \\
\hline 6 & Receivables -6 , other receivables & 0 & 0 \\
\hline 7 & Estimated accrued revenues & 0 & 0 \\
\hline 8 & Advance payments provided & -15 & 0 \\
\hline 9 & Inventory & 13128 & -70 \\
\hline 10 & Tangible fixed assets & 14503 & -78 \\
\hline 11 & Intangible fixed assets & 529 & -3 \\
\hline 12 & Long-term financial assets & 0 & 0 \\
\hline 13 & Payables to members & -1450 & 8 \\
\hline 14 & Payables to controlled and managed persons & 0 & 0 \\
\hline 15 & Payables to accounting units under substantial influence & 0 & 0 \\
\hline 16 & Trade payables & -71 & 0 \\
\hline 17 & Advance payments received & 0 & 0 \\
\hline 18 & Payables to employees (institutions) & -57 & 0 \\
\hline 19 & Other payables & 0 & 0 \\
\hline 20 & Estimated accrued expenses & 0 & 0 \\
\hline 21 & Payables from notes and debentures & 0 & 0 \\
\hline 22 & Credits and loans received & 0 & 0 \\
\hline 23 & Depreciation & 561 & -3 \\
\hline 24 & Adjustments & 0 & 0 \\
\hline 25 & Reserves & 0 & 0 \\
\hline 26 & Gains or losses from acquired property in assets & 0 & 0 \\
\hline 27 & Gains or losses from revaluation of assets and liabilities & 0 & 0 \\
\hline 28 & Gains or losses from capital interest & 0 & 0 \\
\hline 29 & Gains or losses from revaluation in transformations & 0 & 0 \\
\hline 30 & Receivables from adjusted registered capital & 0 & 0 \\
\hline 31 & Accrued revenues & 148 & -1 \\
\hline 32 & Deferred expenses & 56 & 0 \\
\hline 33 & Equity capital & 12338 & -66 \\
\hline 34 & Total revenues from assets and material & 0 & 0 \\
\hline 35 & Total expenses on sale of assets and material & 0 & 0 \\
\hline
\end{tabular}

*EBT and CF non-cash and informative items: changes in values over the reviewed period

** items nos. 1-22 - items for modification of CFm, nos. 23-25 - items for modification of EBTm, nos. 26-33 - informative items, nos. 34-35 - operative items for calculation of CFEBTmo 
and earnings at various levels (grades). The first M-score level works as an analytical test, which provides a decision-maker (user) with information as to how the given accounting unit manages to transform generated earnings into cash flow during at least five accounting periods. If the first M-score level oscillates above the level of significance (10\% materiality is considered here), a test of impacts on financial statements follows in form of a detailed test of the second level of the modified M-score.

Using non-monetary revenues and other adjusting items, the second level of the modified M-score "straightens" CF and EBT in an optimal transformation of profit (loss) before tax in a change of cash flow. In addition, a decision-maker is provided information about significance of those accounting items that contribute to a change of EBT. The modified score should be reduced to an acceptable value of the stated significance (materiality) in order to decrease a risk of accounting errors and frauds.

Consequently, the third M-score level computes the ratio of operating cash flow and modified EBT, which provides information as to whether the selected accounting unit is able to effectively transform the operating costs and revenues into the operating cash flow within a monitored period (five years as a minimum), again after a tax aspect of income tax has been excluded.

In the detailed analysis of an impact risk of accounting errors and frauds, the selected accounting unit generated the following results of the M-score for monitored accounting periods of 2012-2016 (first level is significantly above the materiality threshold stated at $10 \%$, or much highly above the considered materiality).

Tab. I implies that the $1^{\text {st }}$ level of CFEBT M-score is calculated at $108 \%$. This value, which is highly above the materiality level, shows a significant fluctuation between the generation of cash flow and profit (loss) before tax for the monitored period of the first to fifth years in the selected accounting unit. This positive value explains that the accounting unit reached a considerably lower profit (loss) in comparison with the generated cash flow.

Tab. II illustrates individual modification and informative items, including their percentage share in EBT. These data have a great importance for the final evaluation of the risk of manipulation of financial statements based on the overall results of the risk analysis of causes and impacts of accounting errors and frauds.

In the detailed testing of the $2^{\text {nd }} \mathrm{M}$-score level, the discrepancy between EBT and the generation of cash flow increased from $108 \%$ of the $1^{\text {st }}$ level of M-score to $255 \%$, see Tab. I.

The $3^{\text {rd }}$ level of M-score in Tab. I computes a ratio of the generated operating cash flow and EBT after modification by costs that are not transformed into expenses. With respect to the fact that the operative M-score equals $0 \%$, the identified discrepancy between EBT and cash flow considered at the economic substance level was caused outside the operating area of the reported activities of the given accounting unit.

Based on results of the $1^{\text {st }}, 2^{\text {nd }}$ and $3^{\text {rd }}$ levels of M-score, the interconnections between EBT and cash flow may be interpreted as inconsistency having an impact outside the operating area of the selected unit, or, rather, the inconsistency was caused in the financial or investment area.

\section{CFEBT risk triangle-risk of cause of accounting errors and frauds}

To evaluate the risk of cause in the CFEBT risk triangle, the risk level of the selected accounting unit (small enterprise) was assessed in the individual accounting periods. The risk of cause of occurrence

III: Evaluation of risk for 7 financial indicators (ROA) of the selected accounting units during 2012-2016

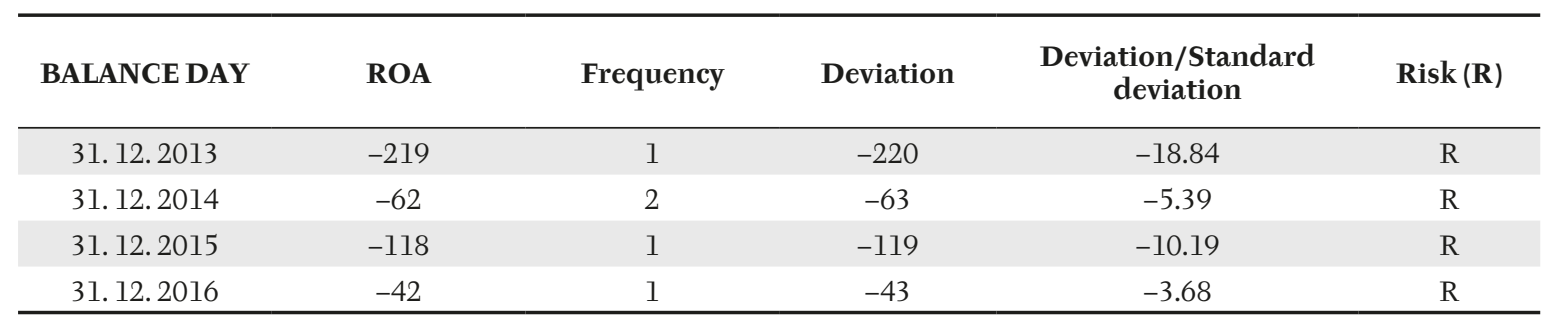

IV: Evaluation of risk for 7 financial indicators (CFA) of the selected accounting units during 2012-2016

\begin{tabular}{|c|c|c|c|c|c|}
\hline 31.12 .2014 & -62 & 1 & -72 & -5.93 & $\mathrm{R}$ \\
\hline 31.12 .2015 & -118 & 1 & -128 & -10.54 & $\mathrm{R}$ \\
\hline
\end{tabular}


was analysed for the selected accounting unit on the basis of the above results of the case study for a sample of small accounting units operating predominantly in building production. A statistical analysis and comparison with the median value of the set for the 7 proposed financial indicators and selected accounting items were conducted: tolerance $5 \%$, narrowing $0 \%$ and certainty 3.5.

Tabs. III and IV present the evaluation of risk areas of deviations from the median value for comparable accounting units, which are assessed as risky units for the reason of exceeding the determined tolerance $5 \%$ and considered certainty 3.5. In accordance with the calculated proportion of deviation and standard deviation, no risk was detected in the risk area of causes of CFEBT risk triangle. The increased risk of occurrence causes of accounting errors and frauds, in comparison with a group of comparable accounting units, was detected for ROA and CFA for the accounting periods 2013, 2014, 2015 and 2016.

In the vertex of the risk of causes, the analysis also evaluates changes of 14 selected accounting items for the monitored period. These values then undergo a calculation of frequency of occurrence, median value for the whole analysed set of comparable accounting units, deviations, including a proportion of deviation to standard deviation.

Based on the evaluated risk items of the analysed set, which included 5,419 elements, the determined parameter for the calculation of 14 accounting items, i.e. tolerance $5 \%$ and certainty 3.5 and the calculation of median value by means of modus, the number of risk items was evaluated for these selected accounting units at $4 \%$ in the area of current assets and payables as regards long-term payables to members, reported only during the accounting period of 2015 at 36\% share in the increase in EBT.

\section{CFEBT risk triangle-evaluation of the risk of causes and impact of accounting errors and frauds}

Based on the calculated $1^{\text {st }}$ to $3^{\text {rd }}$ levels of CFEBT score, the risk of impact of discrepancy between the generation of EBT and cash flow was detected for the analysed period 2012-2016 outside the operating area. During the analysed period, the stock rose by a $70 \%$ share in the increase in EBT, and, in addition, the share in the increase in EBT rose by $78 \%$, which was not followed by an increase in debts or reduction in cash flow, Moreover, the company's equity capital rose by $66 \%$, which does not correspond to the reported negative financial performance as shown for the analysed accounting periods.

Thanks to the interconnection of the financial analysis perspective of the 7 financial indicators in the area of accounting errors and frauds, a significant risk could be detected with respect to Returns of Assets (ROA) and Cash Flow Return on Assets (CFA) for the whole analysed period of 2012-2016. Other findings show that it was only in the year 2015 when debts to members increased and these debts probably generated the reported increase in cash flow. However, in 2016, the accounting unit reported a zero balance of debts to members, which was not followed by a decrease in cash flow.

The comparison of results of the analysis of 2 out of 3 risk areas of the CFEBT triangle of accounting errors and frauds yields a risk of discrepancy between EBT and cash flow, not supported with the economic substance in the areas of stock, cash flow and payables to members.

\section{DISCUSSION}

The present paper performed a risk analysis of manipulation of accounting records beyond the scope of true and fair view of accounting. The risk analysis detected risks using the CFEBT risk triangle of accounting errors and frauds and the causes and impacts thereof from the perspective of users of accounting records for a selected group of accounting units.

An accounting unit was selected for an analysis of specific impacts of accounting errors and frauds and this accounting unit subsequently underwent an analysis of discrepancies between the generation of earnings and the generation of cash flow, using three levels of CFEBT score of impacts. The risk analysis of causes and impacts of accounting errors and frauds in the selected accounting units detected a risk of manipulation of accounting statements in the area of stock the increase in which was not accompanied by the economic substance of the given transaction, i.e. generation of profit.

Previous research carried out by comparison of the CFEBT approach with results of evaluation of selected bankruptcy models (Drábková, ) and models of detection of risks of manipulation of accounting records (Drábková, ) confirmed the efficiency of the complex CFEBT approach, which is based on interconnections between reported accounting information in the context of their economic substance. Despite the efficiency of individual detection models, it may be assumed that the focus of these models is placed on selected techniques of creative accounting and lack in complexity of the development of information reported in time and interconnections.

In our opinion, users of accounting can reduce uncertainty about submitted financial statements only if a complete analysis of financial statements was processed for several years. The CFEBT approach eliminates the diversity of national accounting systems such as the Czech accounting standards, IFRS and US GAAP. We believe that the suggested CFEBT model may be used by auditors to identify risks of accounting frauds in accordance with ISA 240 and by any users of accounting for testing the risk of accounting errors and fraud to do better decision based on them. 


\section{CONCLUSION}

The presented study of detection of risk of accounting errors and frauds interconnects the perspective of a financial analysis and informative capability of accounting from the view of users of accounting records, with the aim of improving the quality of decision-making of these users, on the basis of a small entity operating in agriculture with the number of employees, which is greater than 10 and does not exceed 50 . The analysis compares the reported data of the selected accounting unit with a group of comparable accounting units.

Results of the analysis of 2 out of 3 risk areas of the CFEBT triangle of accounting errors and frauds showed a risk of discrepancy between EBT and cash flow, not supported with the economic substance in the areas of stock, increase in cash flow and payables to members for the monitored period of 2012-2016.

The CFEBT model is considered as a basic comprehensive view of the financial statements and the links between them. The CFEBT risk triangle respects the individuality of the accounts and represents the complex analysis of interconnections of accounting items and their aspects of causes and impacts.

Acknowledgements

This paper was supported by the University of South Bohemia, Faculty of Economics [no. IGS05C1].

\section{REFERENCES}

BALACIU, D. E., BOGDAN, V., FELEDA, L. and POPA, A. L. 2014. Accounting Outside the Box. An Introspective Study on the Colorful Mind of Managers Reflected in Creative Accounting. In: Proceedings of the 9th International Conference Accounting and Management Information Systems, Bucharest Univ Economic Studies, pp. 197-214.

BOLTON, R. J. and HAND, D. J. 2002. Statistical fraud detection: A review. Statistical Science, 17(3): 235-249.

BRODY,R.G.,MELENDY,S.R. andPERRI,F.S.2012. Commentary from the American Accounting Association's 2011 Annual Meeting Panel on Emerging Issues in Fraud Research. Accounting Horizons, 26(3): 513-531.

CAPLAN, D. 1999. Internal controls and the detection of management fraud. Journal of Accounting Research, 37(1): 101-117.

CIMA. 2009. Fraud Risk Management: A Guide to Good Practice. UK: Chartered Global Management Accountant. Available from: http:/www.cimaglobal.com/documents/importeddocuments/cidtechguide_fraud_risk_ management_feb09.pdf [Accessed 25 November 2017].

DAWSON, S. 2015. Internal Control/Anti-Fraud Program Design for The Small Business. UK: John Wiley and Sons Ltd.

DRABKOVA, Z. 2015. Analysis of possibilities of detecting the manipulation of financial statements in terms of the IFRS and Czech accounting standards. Acta universitatis agriculturae et silviculturae Mendelianae Brunensis, 63(6): 1859-1866.

DRABKOVA, Z. 2016. Models of detection of manipulated financial statements as part of the internal control system of the entity. ACRN Oxford Journal of Finance and Risk Perspectives Special Issue of Finance Risk and Accounting Perspectives, 5(1): 227-235.

DRABKOVA, Z. 2017. Fraud Risk Management - An Effective Anti-Fraud System and Decision-Making Tool for Users of Financial Statements. Česko: Tribun EU.

FREE, C. 2015. Looking through the fraud triangle: a review and call for new directions. Meditari Accountancy Research, 23(2): 175-196.

HENSELMANN, K. and HOFMANN, S. 2010. Accounting Fraud: Case Studies and Practical Implications. Germany: Erich Schmidt Verlag GmbH \& Co.

GOODE, S. and LACEY, D. 2011. Detecting complex account fraud in the enterprise: The role of technical and non-technical controls. Decision Support Systems, 50(4): 702-714.

JONES, M. 2011. Creative accounting, Fraud and International accounting scandals. UK: John Wiley and Sons Ltd.

MUI, G. and MALLEY, J. 2015. A tale of two triangles: comparing the Fraud Triangle with criminology's Crime Triangle. Accounting Research Journal, 28(1): 45-58.

PRICEWATERHOUSECOOPERS. 2014. Global Economic Crime Survey 2014. Price Water house Coopers.

Available from: http://www.pwc.com/gx/en/economic-crime-survey/ [Accessed 25 November 2017].

SCHUCHTER, A. and LEVI, M. 2015. Beyond the fraud triangle: Swiss and Austrian elite fraudsters. Accounting Forum, 39(3): 176-187.

SCHUCHTER, A. and LEVI, M. 2016. The Fraud Triangle revisited. Security Journal, 29(2): 107-121.

Contact information

Zita Drábková: drabkova@ef.jcu.cz 